\title{
Kadar Protein, Indeks Putih Telur, dan Nilai Haugh Unit Telur Itik Setelah Perendaman Ekstrak Daun Salam (Syzygium polyanthum) dengan Waktu Penyimpanan yang Berbeda pada
} Suhu $4^{\circ} \mathrm{C}$

\section{The Protein content, Egg White Index and Haugh Unit Value of Duck Egg after soaking in Bay Leaf Ekstract with several preservatif time at $4^{\circ} \mathrm{C}$ Temperature}

\author{
Lia Lestari ${ }^{1}$, Siti Muflichatun Mardiati ${ }^{2}$, Muhammad Anwar Djaelani ${ }^{2}$ \\ ${ }^{1)}$ Program Studi Biologi, Departemen Biologi, Fakultas Sains dan Matematika, Universitas Diponegoro \\ ${ }^{2)}$ Departemen Biologi, Fakultas Sains dan Matematika, Universitas Diponegoro \\ Jl. Prof. Soedarto, SH, Tembalang, Semarang \\ *Email: lialestari174@yahoo.com
}

Diterima 24 Januari 2017 / Disetujui 31 Januari 2018

\begin{abstract}
ABSTRAK
Telur merupakan salah satu bahan pangan yang memiliki nilai gizi tinggi. Penelitian ini bertujuan untuk menganalisis pengaruh perendaman ekstrak daun salam (Syzygium polyanthum) terhadap kadar protein, Indeks Putih Telur (IPT), dan nilai Haugh Unit (HU) pada telur itik. Penelitian ini menggunakan rancangan acak lengkap (RAL) dengan 9 perlakuan dan 5 kali ulangan. Telur yang digunakan sebanyak 45 butir dengan perlakuan pencucian air dan perendaman ekstrak daun salam serta penyimpanan setelah 14 hari dan 28 hari pada suhu $4^{\circ} \mathrm{C}$. Perlakuan terdiri atas P0: kontrol (telur umur satu hari dan tanpa penyimpanan), $\mathrm{P} 1_{14} \mathrm{dan} \mathrm{P} 2_{28}$ : pencucian air, perendaman ekstrak daun salam, $\mathrm{P} 3_{14}$ dan $\mathrm{P} 4_{28}$ : pencucian air, tanpa perendaman ekstrak daun salam, $\mathrm{P}_{14}$ dan $\mathrm{P}_{28}$ : tanpa pencucian air, dengan perendaman ekstrak daun salam, $\mathrm{P}_{14}$ dan $\mathrm{P}_{28}$ : tanpa pencucian air, tanpa perendaman ekstrak air daun salam. Variabel yang diamati yaitu kadar protein telur, IPT, serta nilai HU. Data yang diperoleh dianalisis dengan uji ANOVA pada taraf signifikansi $5 \%$ dan dilanjutkan uji Duncan dengan $\alpha=0,05$. Hasil penelitian menunjukkan bahwa kadar protein tertinggi pada $\mathrm{P} 3_{14}(12,792 \%)$ serta terendah pada $\mathrm{P} 4_{28}(9,85 \%)$, kadar protein pada $\mathrm{P} 7_{14}$ lebih rendah dibandingkan perlakuan yang lain setelah penyimpanan 14 hari. Nilai IPT tertinggi pada $\mathrm{P} 5_{14}(0,079)$ dan terendah pada $\mathrm{P} 8_{28}(0,069)$. Nilai $\mathrm{HU}$ tertinggi pada $\mathrm{P}_{14}(75,116)$ dan terendah pada $\mathrm{P}_{28}(65,924)$. Kesimpulan dari penelitian ini adalah ekstrak air daun salam tidak efektif digunakan untuk mengawetkan telur pada suhu penyimpanan $4^{\circ} \mathrm{C}$.
\end{abstract}

Kata kunci : Telur itik, Haugh unit (HU), Indeks Putih Telur (IPT), protein, daun salam

\section{ABSTRACT}

The Eggs are one of the foods that have high nutritional value. This study aimed to analyze the effect of bay leaf extract (Syzygium polyanthum) to the egg protein content, Egg White Index, and Haugh units (HU) in duck eggs. This study used a completely randomized design (CRD) with 9 treatments and 5 replications. Eggs were used as many as 45 items with the treatment of water washing and soaking in the bay leaf extract also deposit after 14 days and 28 days at $4^{\circ} \mathrm{C}$. $\mathrm{P} 0$ : control (eggs age of one day without storage), $\mathrm{P} 1_{14}$ and $\mathrm{P} 2_{28}$ : washing water, soaking bay leaf extract, $\mathrm{P} 3_{14}$ and $\mathrm{P} 4_{28}$ : washing water, without soaking bay leaf extract, $\mathrm{P} 5_{14}$ and $\mathrm{P}_{28}$ : without washing water, with soaking bay leaf extract, $\mathrm{P} 7_{14}$ and $\mathrm{P}_{28}$ : without washing water, without soaking bay leaf extract. Variables observed that the levels of protein, egg white index, and HU. Data were analyzed by ANOVA at a significance level of 5\% and a continued test of Duncan with $\alpha=0.05$. The results of this study showed that the highest protein content on $\mathrm{P} 3_{14}(12.792 \%)$ and the lowest was in $\mathrm{P} 4_{28}(9.85 \%)$, but the levels of protein in $\mathrm{P}_{14}$ was lower than other treatments after 14 days of storage. The egg white index the highest value was in $\mathrm{P}_{14}(0.079)$ and the lowest was in $\mathrm{P} 8_{28}(0.069)$. The HU highest value shown in $\mathrm{P}_{14}$ (75.116) and the lowest at $\mathrm{P} 8_{28}$ (65.924). The conclusion of this study was the water extract of the bay leaf was not able to maintain the quality of duck eggs were seen in the levels of protein, IPT, and HU.

Keywords : Local duck eggs, Haugh unit, egg white index, protein, bay leaf 


\section{PENDAHULUAN}

Telur merupakan salah satu sumber protein hewani di samping daging, ikan, dan susu (Suprapti, 2002). Telur yang dijual dipasaran tersimpan sekitar tujuh hari. Telur tersebut masih menunjukkan kualitas yang baik ditinjau dari haugh unit dan bobot telur. Telur yang disimpan dalam suhu kamar selama 25 hari tanpa perlakuan apapun akan menurunkan kualitas telur ditinjau dari haugh unit dan indeks putih telur. Kualitas telur dapat diamati dengan cara melakukan pengukuran terhadap indeks kuning telur (IKT), indeks putih telur (IPT), rongga udara, bobot telur, dan haugh unit (HU). Telur yang disimpan lama nilai IKT, IPT dan HU akan mengalami penurunan (Fibrianti dkk., 2012).

Perubahan luar pada telur yang mengalami kerusakan, yaitu adanya penurunan berat, pembesaran kantung udara, dan timbulnya bercak pada permukaan kerabang telur. Perubahan luar, yaitu perubahan yang dapat diamati tanpa melakukan pemecahan pada telur (Winarno dan Koswara, 2002). Daya simpan telur sebagai bahan pangan perlu dipertahankan agar tetap mempunyai kualitas yang tinggi dengan melakukan pengawetan yang benar karena dengan pengawetan maka proses kerusakan atau perubahan di dalam telur dapat diperlambat (Gaman dan Sherrington, 1994). Faktor-faktor yang menyebabkan telur cepat mengalami kerusakan diantaranya adalah terjadinya proses penguapan, hilangnya $\mathrm{CO}_{2}$ melalui pori kerabang telur, dan masuknya mikroorganisme ke dalam telur yang akan menguraikan protein yang terdapat di dalam telur (Yuwanta, 2010). Salah satu cara mempertahankan mutu telur supaya dapat tahan lama adalah dengan cara melakukan perendaman atau pelapisan dengan cairan, yaitu dilakukan dengan cara merendam telur segar dalam berbagai larutan seperti air kapur, larutan air garam dan filtrat atau penyamak nabati yang mengandung tanin (Syarief dkk., 1990).

Tanaman salam merupakan tanaman berkayu yang mengandung saponin, triterpen, flavonoid, tanin, dan alkaloid serta biasanya bagian yang sering dimanfaatkan adalah daun (Sudirman, 2014). Komponen anti-mikroba yang terkandung di dalam daun salam berupa minyak atsiri, tanin, dan flavonoid. Ketiga komponen tersebut dapat berfungsi sebagai antimikroba karena mengandung gugus $\mathrm{OH}$ yang dapat melunturkan komponen lemak yang menyusun dinding sel mikroba (Cornelia dkk., 2005).

Tanin merupakan senyawa fenol yang berfungsi untuk menghambat pertumbuhan bakteri dengan memunculkan denaturasi protein dan menurunkan tegangan permukaan, sehingga permeabilitas bakteri meningkat serta menurunkan konsentrasi ion kalsium, menghambat produksi enzim, dan menganggu proses reaksi enzimatis pada bakteri, sehingga menghambat terjadinya koagulasi plasma (Sudirman, 2014). Ajizah (2004), menyatakan bahwa tanin mempunyai daya antibakteri dengan cara mempresipitasi protein. Karmila dkk. (2008), menjelaskan bahwa tanin akan bereaksi dengan protein yang terdapat pada kerabang telur yang mempunyai sifat menyerupai kolagen kulit hewan sehingga terjadi proses penyamakan kulit berupa endapan berwarna cokelat yang dapat menutup pori kerabang telur tersebut menjadi impermeable (tidak dapat tembus) terhadap gas dan udara, sehingga mampu memperkecil penguapan air serta hilangnya $\mathrm{CO}_{2}$ melalui kerabang telur.

Tujuan dari penelitian ini adalah untuk menganalisis pengaruh perendaman ekstrak daun salam (Syzygium polyanthum) terhadap kadar protein, Indeks Putih Telur (IPT), dan nilai Haugh Unit (HU) pada telur itik.

\section{METODE PENELITIAN}

Penelitian ini dilakuakan di Laboratorium Biologi Struktur dan Fungsi Departemen Biologi Fakultas Sains dan Matematika Universitas Diponegoro Semarang, penelitian dilakukan dari bulan Juni-Agustus 2016.

Alat yang digunakan pada penelitian ini yaitu egg tray, timbangan digital, jangka sorong, kaca bidang datar, alat tulis, kalkulator, kompor, baskom, tususk gigi, lemari es, dan panci. Bahan yang digunakan pada penelitian yaitu telur itik sebanyak 45 butir yang berumur 1 hari dan daun salam. 


\section{Pengambilan Sampel}

Telur itik diambil dari peternak Pandansari, Semarang, berumur satu hari sebanyak 45 butir, kemudian telur dibersihkan dari kotoran dan diletakkan pada egg tray.

\section{Pencucian Telur}

Media yang biasa digunakan untuk membersihkan telur konsumsi adalah dengan air mengalir (Fibrianti dkk., 2012). Telur itik dicuci dengan air mengalir kemudian dikeringkan dan ditimbang satu per satu untuk mengetahui berat awal dan dikelompokkan sesuai dengan perlakuan masing-masing. Pengamatan dilakukan setelah penyimpanan selama 14 hari dan 28 hari.

\section{Pembuatan Ekstrak Daun Salam}

Ekstraksi daun salam menggunakan pelarut air dilakukan dengan pemanasan (hingga mendidih). Daun salam segar dihancurkan dengan blender sampai halus lalu dicampur air dengan perbandingan $2 \mathrm{~kg}$ daun salam : 4 liter air. Ekstraksi daun salam dilakukan dengan metode pemanasan hingga mendidih pada suhu $100^{\circ} \mathrm{C}$ selama 30 menit (Cornelia dkk., 2005). Hasil ekstrak daun salam dianalisis kandungan taninnya secara spektrofotometri.

\section{Perendaman Telur dengan Ekstrak Daun Salam}

Ekstrak daun salam didinginkan terlebih dahulu sampai suhunya menurun dari $100^{\circ} \mathrm{C}$ menjadi $30^{\circ} \mathrm{C}$. Telur direndam ke dalam ekstrak daun salam sampai semua permukaan telur terendam. Perendaman dilakukan selama 30 menit (Asjayani, 2014), setelah itu telur disimpan pada suhu $4^{\circ} \mathrm{C}$ dilakukan secara acak dengan metode pengundian.

\section{Pengukuran Kadar Protein}

Kadar protein telur yang diukur adalah kadar protein telur utuh (kuning dan putih telur). Analisis kimia kadar protein telur dilakukan dengan metode Kjeldahl.
Metode Kjeldahl terdapat tiga tahap pengerjaan yaitu tahap dekstruksi, tahap destilasi dan tahap titrasi. Sampel didestruksi dengan asam sulfat dan dikatalisis dengan katalisator yang sesuai sehingga akan menghasilkan amonium sulfat, setelah ditambah dengan alkali kuat ammonia yang terbentuk didestilasi uap secara kuantitatif ke dalam larutan penyerap dan selanjutnya ditetapkan dengan titrasi. Cara Kjehdahl pada umumnya dapat dibedakan atas dua cara yaitu cara makro dan semi mikro. Cara makro Kjehdahl digunakan untuk contoh yang sukar dihomogenisasi dan besar contoh $1-3$ g, sedang semi mikro Kjehdahl dirancang untuk contoh ukuran kecil yaitu kurang dari 3000 mg dari (Rohmman dan Sumantri, 2007).

\section{Indeks Putih Telur (IPT)}

Tinggi putih telur diukur pada bagian albumen kental (thick albumen) dengan cara menusukkan suatu batang kayu kecil (lidi) pada bagian tersebut. Bagian lidi yang masuk ke dalam putih telur merupakan tinggi putih telur; kemudian bagian tersebut diukur menggunakan jangka sorong. Hasil pengamatan Indeks Putih Telur dicatat pada tabel hasil pemeriksaan (Fibrianti dkk., 2012). Rumus Indeks Putih Telur seperti yang digunakan Fibrianti dkk., (2012) adalah :

$$
\frac{\mathrm{T}}{\frac{1}{2}(\mathrm{~L} 1+\mathrm{L} 2)}
$$

Keterangan: $\mathrm{T}$ : Tinggi Putih Telur, $\mathrm{L}_{1}$ : Lebar Putih Telur, $\mathrm{L}_{2}$ : Panjang Putih Telur.

\section{Haugh Unit (HU)}

HU diukur dengan mengukur tinggi albumen kental (thick albumen) menggunakan mikrometer yang terpasang pada tripod. Tinggi albumen kental diukur pada 3 titik dengan jarak $10 \mathrm{~mm}$ dari yolk, kemudian dihitung rata-ratanya. HU dihitung berdasarkan rumus (Silversides dan Villeneuve, 1994) :

$$
\text { Haugh Unit }=100 \log \left(\mathrm{H}+7,57-1.7 \mathrm{~W}^{0,37}\right),
$$

Keterangan : $\mathrm{H}=$ tinggi putih telur kental $(\mathrm{mm}), \mathrm{W}=$ berat telur $(\mathrm{g})$. 


\section{HASIL DAN PEMBAHASAN}

\section{Kadar Protein Telur Itik}

Kadar protein telur itik setelah perlakuan pencucian dan perendaman ekstrak daun salam serta penyimpanan setelah 14 hari dan 28 hari pada suhu $4^{\circ} \mathrm{C}$ disajikan pada Gambar 1. Hasil analisis menunjukkan bahwa perlakuan P0 berbeda nyata terhadap telur setelah penyimpanan 14 hari dan 28 hari, serta memiliki kadar protein paling tinggi dari semua perlakuan. Yuwanta (2010), menyatakan bahwa kadar protein telur segar antara 12,8\% $13,4 \%$. Kadar protein pada penyimpanan 14 hari dan 28 hari memiliki kadar protein lebih rendah dibandingkan P0. Saraswati (2015), menambahkan semakin lama telur disimpan, maka $\mathrm{pH}$ dalam telur akan meningkat karena penguapan $\mathrm{CO}_{2}$ sehingga menyebabkan ion bikarbonat berkurang, akibatnya kemampuan buffer telur akan berkurang dan putih telur menjadi encer.

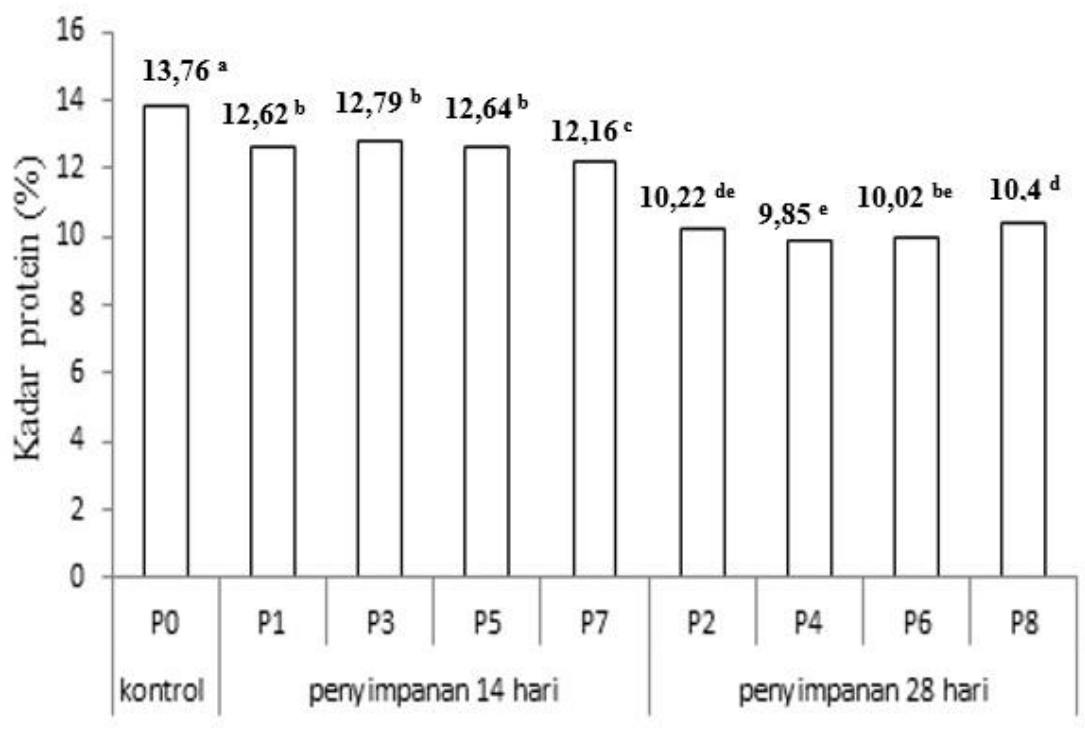

Gambar 1. Histogram kadar protein telur itik setelah perendaman ekstrak daun salam (Syzygium polyanthum) dengan waktu penyimpanan yang berbeda pada suhu $4^{\circ} \mathrm{C}$

Keterangan: angka yang diikuti superskrip yang berbeda menunjukkan hasil yang berbeda nyata $(\mathrm{P}<0,05)$.

Kadar protein telur setelah penyimpanan 14 hari, pada perlakuan $\mathrm{P}_{14}$ berbeda nyata dengan $\mathrm{P} 1_{14}, \mathrm{P} 3_{14}$, dan $\mathrm{P} 5_{14}$, diduga karena tidak adanya perlakuan pada telur (tanpa perendaman ekstrak daun salam), sehingga $\mathrm{P} 7_{14}$ memiliki kadar protein paling rendah di antara semua perlakuan pada penyimpanan telur setelah 14 hari. Sudaryani (2003), menyatakan telur akan mengalami penurunan kualitas seiring dengan lama penyimpanan. Yuwanta (2010), menambahkan perubahan $\mathrm{CO}_{2}$ pada telur mengakibatkan perubahan $\mathrm{pH}$ telur yang semula 7,4 (saat ditelurkan) menjadi 9,2-9,5 selama 3-6 hari penyimpanan sehingga menyebabkan air pada putih telur meningkat. Perubahan $\mathrm{pH}$ putih telur digunakan sebagai salah satu kriteria kualitas putih telur. Perlakuan $\mathrm{P} 1_{14}, \mathrm{P} 3_{14}$, dan $\mathrm{P} 5_{14}$ tidak berbeda nyata, hal ini menunjukkan bahwa adanya perlakuan perendaman ekstrak daun salam pada telur tidak berpengaruh terhadap kadar protein. Hasil uji menunjukkan bahwa kadar tanin pada daun salam hanya $3,74 \%$, diduga kadar tanin yang terdapat dalam ekstrak daun salam kurang sehingga tidak dapat mempertahankan kadar protein telur atau mengawetkan telur.

Protein telur mengalami penurunan seiring dengan lamanya waktu penyimpanan. Kadar protein telur setelah penyimpanan 28 hari, yaitu 9,85\%-10,4\%. Yuwanta (2010), menambahkan perubahan putih telur sebagai akibat dari pertukaran gas antara udara luar dengan isi telur melalui pori kerabang sehingga menyebabkan telur kehilangan 
air karena evaporasi. Evaporasi terjadi secara linear dengan waktu penyimpanan dan mengakibatkan terjadinya perluasan pada rongga udara. Perlakuan $\mathrm{P}_{28}$ berbeda nyata dengan $\mathrm{P} 8_{28}$, diduga adanya pencucian pada telur menyebabkan lapisan kutikula hilang sehingga menyebabkan mikroorganisme luar masuk ke dalam telur, ini didukung oleh Park et al. (2003), menyatakan adanya perlakuan pencucian dengan tangan menyebabkan kutikula pada telur hilang sehingga permukaan kerabang telur halus dan mengalami keretakan.

\section{Indeks Putih Telur (IPT)}

IPT telur itik setelah perlakuan pencucian dan perendaman ekstrak daun salam serta penyimpanan setelah pada Gambar 2. Hasil analisis menunjukkan bahwa $\mathrm{P} 0$ berbeda nyata dengan semua perlakuan $\left(\mathrm{P} 1_{14}, \mathrm{P} 2_{28}, \mathrm{P} 3_{14}, \mathrm{P} 4_{28}\right.$, $\mathrm{P} 5_{14}, \mathrm{P}_{28}, \mathrm{P} 7_{14}$, dan $\mathrm{P} 8_{28}$ ), dimungkinkan adanya penyimpanan pada telur sehingga nilai IPT mengalami penurunan setelah penyimpanan 14 hari dan 28 hari dibandingkan dengan nilai IPT pada P0. Sesuai dengan hasil penelitian yang dilakukan oleh Park et al. (2003), mengenai pengaruh berbagai macam perlakuan pada kerabang telur terhadap kualitas telur selama waktu penyimpanan, mengungkapkan bahwa IPT telur pada suhu $4^{\circ} \mathrm{C}$ dan $30^{\circ} \mathrm{C}$ mengalami penurunan selama penyimpanan. Penurunan IPT pada suhu $30^{\circ} \mathrm{C}$ lebih besar dibandingkan pada suhu $4^{\circ} \mathrm{C}$. Suhu $30^{\circ} \mathrm{C}$ IPT mengalami penurunan pada penyimpanan 17 hari, sedangkan pada suhu $4^{\circ} \mathrm{C}$ IPT mampu bertahan selama 30 hari. Samli et al. (2005) menjelaskan bahwa adanya penurunan IPT disebabkan karena hilangnya $\mathrm{CO}_{2}$ dan terjadinya pemecahan asam karbonat menjadi $\mathrm{CO}_{2}$, sehingga menyebabkan serat musin kehilangan struktur yang memberikan tekstur kental pada albumen telur, sehingga albumen menjadi encer.

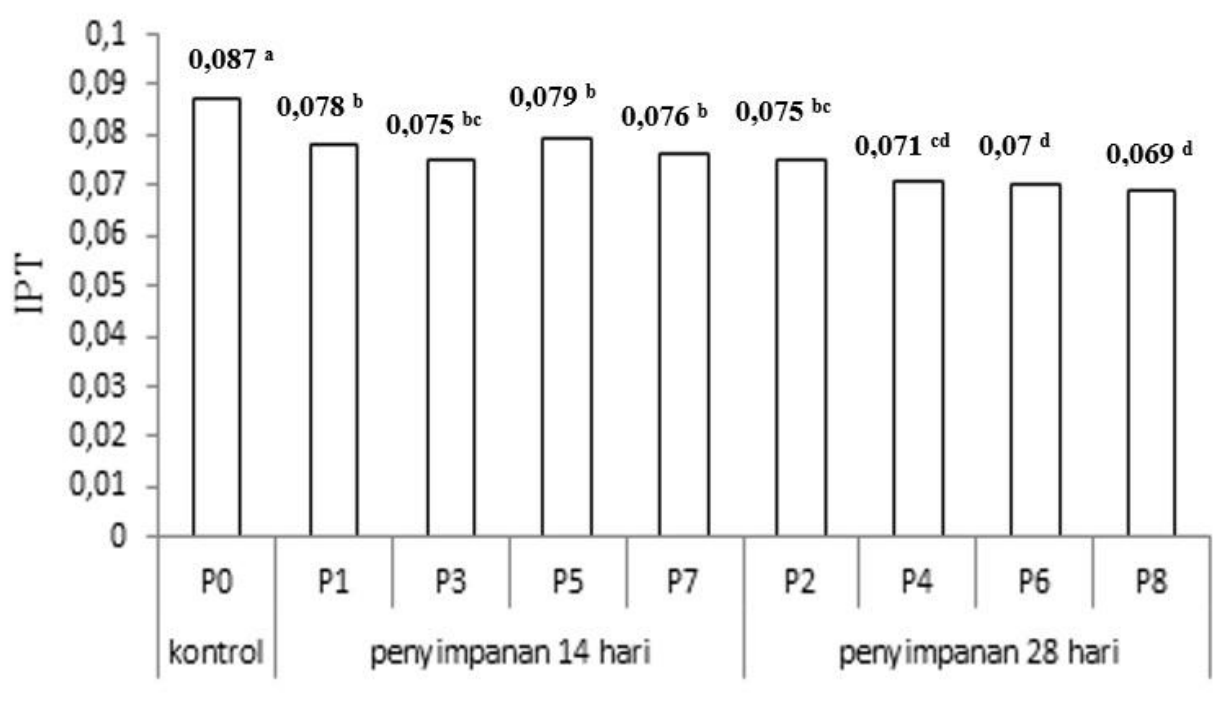

Gambar 2. Hitogram indeks putih telur (IPT) setelah perendaman ekstrak daun salam (Syzygium polyanthum) dengan waktu penyimpanan yang berbeda pada suhu $4^{\circ} \mathrm{C}$.

Keterangan: angka yang diikuti superskrip yang berbeda menunjukkan hasil yang berbeda nyata $(\mathrm{P}<0,05)$.

IPT telur setelah penyimpanan 14 hari dan 28 pada suhu $4^{\circ} \mathrm{C}$ masih relatif tinggi. Hal ini didukung oleh BSN (2008), bahwa indeks putih telur segar berkisar antara 0,050-0,174. Nilai IPT telur pada penyimpanan setelah 14 hari dan 28 hari memiliki nilai yang sama pada semua perlakuan. Hal ini dapat dilihat dari perlakuan $\mathrm{P}_{14}, \mathrm{P}_{14}, \mathrm{P} 5_{14}$, $\mathrm{P}_{14}, \mathrm{P} 2_{28}, \mathrm{P}_{28}, \mathrm{P}_{28}$ dan $\mathrm{P}_{28}$ yang tidak berbeda nyata, diduga perlakuan perendaman ekstrak daun salam pada telur itik tidak berpengaruh nyata 
terhadap IPT, dimungkinkan kadar tanin yang terdapat dalam ekstrak daun salam kurang sehingga tidak dapat meningkatkan nilai IPT pada telur.

\section{Nilai Haugh Unit (HU)}

Nilai HU telur itik setelah perlakuan pencucian dan perendaman ekstrak daun salam, penyimpanan 14 hari dan 28 hari pada suhu $4^{\circ} \mathrm{C}$ disajikan pada Gambar 3. Data menunjukkan bahwa HU P0 tidak berbeda nyata dengan HU telur setelah penyimpanan 14 hari $\left(\mathrm{P} 1_{14}, \mathrm{P} 3_{14}, \mathrm{P} 5_{14}\right.$,
P7 14 ), tetapi semakin lama waktu penyimpanan maka nilai $\mathrm{HU}$ mengalami penurunan karena adanya penguapan air dan hilangnya $\mathrm{CO}_{2}$ melalui pori kerabang telur, sehingga hal tersebut menyebabkan HU P0 berbeda nyata dengan HU telur setelah penyimpanan 28 hari $\left(\mathrm{P}_{28} . \mathrm{P}_{28}, \mathrm{P}_{28}\right.$, $\mathrm{P}_{28}$ ), sesuai dengan Almeida et al. (2014), bahwa telur yang disimpan pada pendingin akan menurunkan kualitas telur, tetapi penurunan kualitas telur lebih besar jika disimpan pada suhu ruangan.

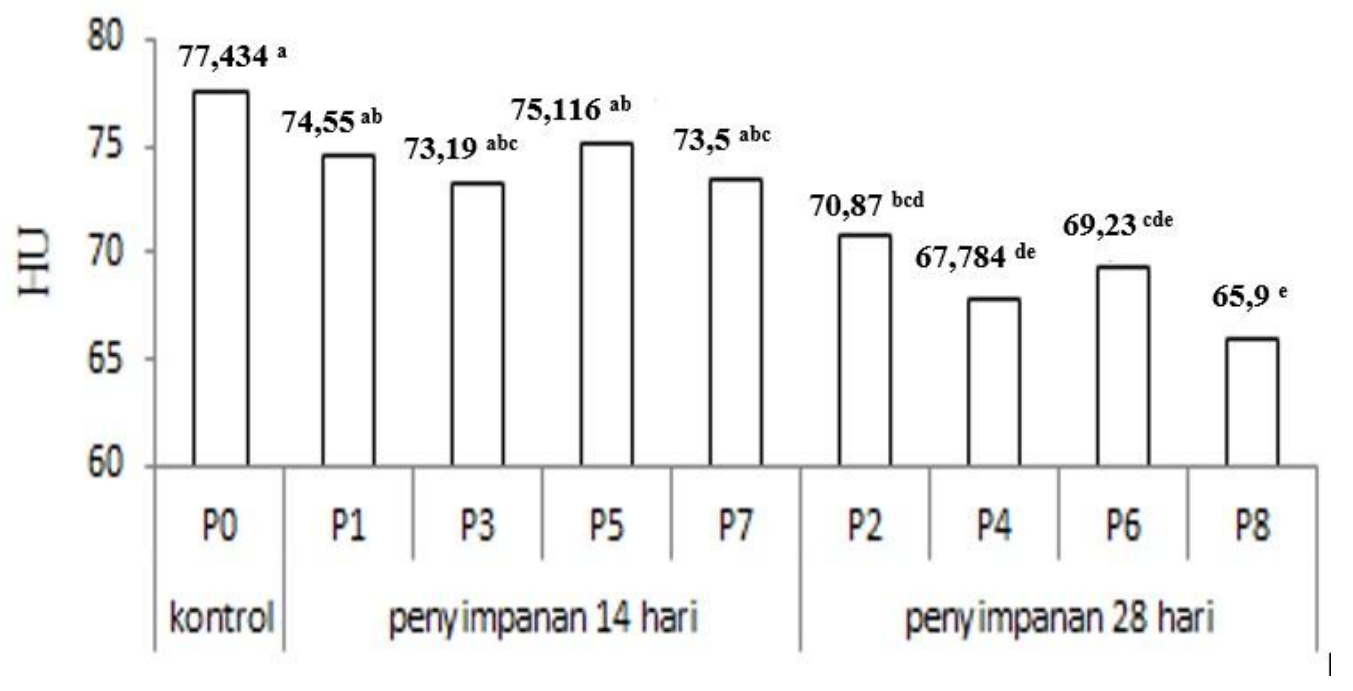

Gambar 3. Histogram haugh unit (HU) setelah perendaman ekstrak daun salam (Syzygium polyanthum) dengan waktu penyimpanan yang berbeda pada suhu $4^{\circ} \mathrm{C}$.

Keterangan: angka yang diikuti superskrip yang berbeda menunjukkan hasil yang berbeda nyata $(\mathrm{P}<0,05)$.

Nilai HU telur itik setelah penyimpanan 14 hari dan 28 hari pada suhu $4^{\circ} \mathrm{C}$ memiliki nilai yang tidak berbeda nyata pada semua perlakuan. Hal ini menunjukkan jika adanya perlakuan perendaman esktrak daun salam tidak berpengaruh terhadap HU telur, diduga kurangnya kadar tanin dalam ekstrak daun salam sehingga tidak dapat meningkatkan nilai $\mathrm{HU}$ telur. Kualias $\mathrm{HU}$ telur itik sampai penyimpanan 28 hari pada suhu $4^{\circ} \mathrm{C}$ masih memiliki kualitas yang baik dengan grade antara AAA $(65,924-75,116)$. USDA (2000), menambahkan jika HU telur dengan kualitas AA (100 sampai 72), B (71 sampai 60), C (dibawah 29). Semua telur dengan penyimpanan suhu dibawah $8^{\circ} \mathrm{C}$ diklasifikasikan AA atau sangat baik.

\section{KESIMPULAN}

Kesimpulan dari penelitian ini adalah ekstrak air daun salam tidak efektif digunakan untuk mengawetkan telur pada suhu penyimpanan $4^{\circ} \mathrm{C}$.

\section{DAFTAR PUSTAKA}

Ajizah, A. 2004. Sensitivitas Salmonella typhymurium terhadap Ekstrak Daun Jambu Biji (Psidium guajava L.). Bioscientiae. 

polyanthum) dengan Waktu Penyimpanan yang Berbeda pada Suhu $4^{\circ} \mathrm{C}$

Volume I, No. 1. Program Studi Biologi FMIPA Universitas Lambung, Mangkurat.

Almeida de D.Y., A.F. Schneider, F.M. Yuri, B.D. Machado, and C.E Gewehr. 2014. Egg Shell Treatment Methods Effect on Commercial Eggs Quality. Universidade do Estado de Santa Catarina (UDESC), Brasil.

Asjayani, R. 2014. Aplikasi Ekstrak Daun Eceng Gondok (Eichornia crassipes) pada Level dan Lama Simpan Terhadap Kualitas Telur Ayam Ras. Skripsi. Universitas Hasanudin, Makassar.

BSN (Badan Standarisasi Nasional). 2008. Telur Ayam Konsumsi. SNI 01-3926- 2008. BSN, Jakarta.

Cornelia, M., C.C. Nurwitri, Manissjah. 2005. Peranan Ekstrak Kasar Daun Salam (Syzygium polyanthum (Wight) Walp.) dalam Pertumbuhan Total Mikroba dan Escherichia coli pada Daging Ayam Segar. Jurnal. Ilmu dan Teknologi Pangan.

Fibrianti, S.M., I Ketut Suada, Mas Djoko Rudyanto. 2012. Kualitas Telur Ayam Konsumsi yang Dibersihkan dan Tanpa Dibersihkan Selama Penyimpanan Suhu Kamar. Indonesia Medicus Veterinus, Indonesia.

Gaman, P.M dan K.B. Sherrington. 1994. Ilmu Pangan : Pengantar Ilmu Pangan Nutrisi dan Mikrobiologi Edisi ke 2. Gadjah Mada University Press, Yogyakarta.

Karmila. M., Maryati, dan Jusmawati. 2008. Pemanfaatan Daun Jambu Biji (Psidium guajava L.) sebagai Alternatif Pengawetan Telur Ayam Ras. UNM, Makassar.

Park, Y.S., I.J. Yoo, K.H. Jeon, H.K. Kim, E.J. Chang and H.I. Oh. 2003. Effects of Various Eggshell Treatments on The Egg Quality during Storage. J. Anim. Sci, Korea.
Rohman, A., dan Sumantri. 2007. Analisis Makanan. Gadjah Mada University-Press, Yogyakarta.

Samli, H.E., A. Agna, and N. Senkoylu. 2005. Effects of Storage Time and Temperature on Egg Quality in Old Laying Hens. J. Appl. Poult. Res.

Saraswati, T.R. 2015. Optimalisasi Fungsi Reproduksi Puyuh dan Biosintesis Kimiawi Bahan Pembentuk Telur. LESKONFI, Jakarta.

Silversides, F.G., and Villeneuve. 1994. Is The Haugh Unit Correction for Egg Weight Valid For Eggs Stored at RoomTemperature. Poultry Science. 73: 50-55.

Sudaryani, T. 2003. Kualitas Telur. Penebar Swadaya, Jakarta.

Sudirman, A.T. 2014. Uji Efektivitas Ekstrak Daun Salam (Eugenia polyantha) terhadap Pertumbuhan Staphylococcus aureus secara In Vitro. Skripsi. Fakultas Kedokteran Gigi. Universitas Hasanuddin, Makassar.

Suprapti, M.L. 2002. Pengawetan Telur. Kanisius, Yogyakarta.

Syarief dan H. Halid. 1990. Buku Monograf Teknologi Penyimpanan Pangan. Laboratorium Rekayasa Pangan dan Gizi. Institut Pertanian Bogor, Bogor.

Unites States Departement of Agriculture - USDA. 2000. Egg-grading Manual. Departament of Agriculture, Washington.

Winarno, F.G., dan S. Koswara. 2002. Telur: Komposisi, Penanganan dan Pengolahannya. M-Brio Press, Bogor.

Yuwanta, T. 2010. Telur dan Kualitas Telur. Gadjah Mada University Press, Yogyakarta. 